\title{
Quality analysis of Makgeolli made with non-steamed rice flour Nuruk by various fungal strains
}

\author{
Cheol-Gyo Lee, Ji-Hoon Na, Sang-Jun Park, Jae-Hee Jeong, Cheol-Min Kim, \\ Bok-seon Kim, Hong-Bi Han, Chang-Ki Huh* \\ Department of Food Science and Technology, Sunchon National University, Suncheon 57922, Korea
}

\section{곰팡이 균주별 무증자 쌀가루 개량누룩을 첨가한 막걸리의 품질특성}

\author{
이철교 · 나지훈 · 박상준 · 정재희 · 김철민 · 김복선 · 한홍비 · 허창기* \\ 순천대학교 식품공학과
}

\begin{abstract}
An easy and simple method of producing Nuruk using rice was developed. In addition, the quality characteristics of the prepared Nuruk were evaluated for Makgeolli production. A comparison of the enzyme activities between A. kawachii rice Koji (RK) and non-steamed rice flour Nuruk according to the fungal strain revealed the $\beta$-amylase activity of $A$. oryzae rice flour Nuruk (AON) to be the highest at $3697.85 \mathrm{SP} / \mathrm{g}$. The a-amylase activity and protease activity were highest at 111.67 A.U and 33.23 tyrosine $\mathrm{mg} / \mathrm{min}$ of $P$. candidum rice flour Nuruk (PCN), respectively. The ethanol contents of the four samples were similar at $16.1-16.4 \%$. The sensory evaluation result showed that Makgeolli made with PCN had the highest preference score of 5.78 and showed a significant difference in overall preference. Moreover, Makgeolli made with PCN showed a higher preference than of Makgeolli made with RK. The titratable acidity and reducing sugar content of Makgeolli made with PCN were $0.48 \%$ and $4.14 \%$, respectively, which were higher than those of Makgeolli made with RK. The ethanol content of Makgeolli made with PCN was $\mathbf{1 5 . 1 0 \%}$, which showed a $\mathbf{1 2 . 8 0} \%$ higher ethanol production yield than that of Makgeolli made with RK. Therefore the PCN produced in this study will be effective for Makgeolli production.
\end{abstract}

Key words : rice flour, non-steamed rice flour Nuruk, rice Koji, Penicillium candidum, Makgeolli

\section{서 론}

술은 탄수화물 등의 원료 성분이 젖산, 곰팡이 등의 미생 물 분해작용과 알코올 발효를 통해 당, 유기산 등의 여러 성분이 함유된 발효음료이다. 발효원으로는 전분질을 함유 하는 곡류와 당분을 주성분으로 하는 과실류 등이 있으며 (1), 전통주의 대표적인 약주, 탁주 양조법은 백미, 찹쌀 등의 원료를 사용하여 병행복발효로 진행되고, 양조 후에 술덧을 체로 걸러 외관이 탁한 것을 탁주라고 하며, 술덧에

*Corresponding author. E-mail : hck1008@sunchon.ac.kr Phone : 82-61-750-3251, Fax : 82-61-750-3208

Received 01 July 2019; Revised 07 August 2019; Accepted 07 August 2019.

Copyright (c) The Korean Society of Food Preservation. All rights reserved.
용수(익은 술독 안에 박아 넣어서 맑은 술을 얻는 데 사용하 는 도구)를 박아서 맑은 액만을 취한 것을 약주라고 한다(2) 그 중 탁주는 농경문화를 주체로 해 온 우리 민족에게는 매우 중요한 발효식품으로 “농주”라고 불려왔다(3). 다른 주류와는 달리 영양성분이 풍부하게 함유되어 있으며 특히 인체 신진대사에 관여하는 필수 아미노산인 lysine, leucine, glutamic acid, proline 및 glutathione이 함유되어 있다. 또한 풍미 성분인 ester류와 산미에 관여하며 갈증을 해소하는 유기산, acetylcholine이 함유되어 있다(4). 발효제는 전분을 당화시키는 효소를 함유하는 곰팡이를 배양한 것으로 누룩 과 입국 등으로 분리된다(5). 주조에 사용되는 원료인 누룩 은 제조법에 따라 자연 중 존재하는 미생물의 번식에 의해 만들어지는 재래누룩과 전분질 원료에 배양한 균을 접종하 여 만드는 개량 누룩으로 분류되며(6), 가공되지 않은 곡류 자체가 가지고 있는 효소와 접종된 곰팡이 등의 기타 균류 
가 번식하여 여러 종류의 효소를 생성하는 발효 starter의 한 종류로 환경, 원재료, 지역에 따라 고유의 풍미와 특성을 나타낸다(7). 주 원료로 밀을 사용하며 지역마다 옥수수, 보 리, 대두, 백미 등의 곡류가 사용되기도 한다. 누룩에는 여러 종류의 미생물이 생 육하므로 첨가량에 따라 효소활성, 유 기산 생산능 및 에탄올 발효력이 달라 탁주의 풍미, 맛 및 색 등 품질차이가 발생한다(8). 1945년 이전 누룩에는 Aspergillus 속이 주종을 이루었으며 Rhizopus속, Absidia속, Mucor속순으로 분리되었다(9). 1945년부터 1990년대 누 룩에서는 1945년 이전에는 분리되지 않았던 Penicillium, Hansenula, Pichia, Bacillus, Lactobacillus, Leuconostoc속 등이 주요 균총으로 나타났다(10). 쌀은 왕겨와 겨 층을 벗 겨내어 먹을 수 있게 가공한 것으로 오랜 기간 주식으로 이용되어왔다. 또한 탄수화물, 단백질, 지질, 회분, 조섬유 등으로 구성되어 있으며 인, 칼슘, 철분 등의 무기질 및 비타민, 나이아신, 필수아미노산인 라이신 등이 포함되어 있다(11). 또한 보리, 밀과 함께 세계적으로 중요한 농산물 이다. 세계 총 생산량의 약 $92 \%$ 는 아시아에서 생산되고, 또 그 대부분을 아시아 사람들이 섭취하고 있다. 한국도 쌀의 주요 생산국의 하나이며 주식으로서 사랑받고 있다. 국내에서도 쌀은 전라남도에서 가장 많이 생산하고 있으며 2018년 쌀 생산량 386만 8천 톤 중 약 76.6만 톤을 생산해내 고 있다(2018년 기준). 그러나 매년 1인당 쌀 소비량은 2009 년 $74.0 \mathrm{~kg}, 2012$ 년 $69.8 \mathrm{~kg}, 2018$ 년 $61.0 \mathrm{~kg}$ 으로 줄어들고 있으며 쌀의 생산량 또한 2009년 492만 톤, 2012년 401만 톤이었으며 2018년에는 387만 톤에 그치고 있다. 따라서 쌀 소비 촉진을 위한 일환으로 전통식품의 원료가 되는 쌀을 이용해 개량누룩을 개발함으로써 쌀 생산과 소비의 촉진이 필요한 시점이다. 전통주의 재료가 되는 쌀을 이용 한 쌀 코지(입국)는 고두밥을 제조하고 냉각 후 균을 첨가해 보쌈하며 배양 후 건조 과정을 통해 제조된다. 이처럼 제조 과정이 까다로우며 고두밥 제조 기술 및 적절한 온도 및 습도 등을 섬세하게 관리할 수 있는 기술이 요구된다. 기술 적 결함 발생 시, 잡균의 오염이 발생할 수 있으며 온도 관리 실패 시 술덧 제조에 실패하게 된다. 또한 쌀 코지를 균일하게 제조할 수 없고 완성된 술에서 불쾌한 풍미를 나타낼 수 있다는 단점이 존재한다(12). 그러나 개발하고자 하는 쌀가루를 이용한 개량 누룩의 제조는 쌀가루 자체에 온수를 이용한 익반죽 후 균을 첨가해 반죽하고 배양하는 공정으로 기존의 코지 제조 공정에 비해 과정이 복잡하지 않다. 또한 고두밥 제조 과정 및 보쌈 과정을 생략함으로써 균일한 쌀가루 누룩의 제조 및 술덧 제조의 성공률을 높일 수 있다. 국내 전통 약주, 탁주와 관련된 연구는 발효미생물 및 공정개발에 관련된 연구에 치우쳐있으며, 쌀가루를 이 용한 다양한 가공식품 $(13,14)$ 등의 연구가 활발히 진행되고 있으나 쌀가루를 이용해 발효적성 탐색 및 누룩 제조 연구 등은 아직 미진한 실정이다. 따라서 본 연구에서는 쌀을
이용한 누룩의 제조 방법을 현장에서 손쉽고, 공정이 간편 한 제조기술로 개발하기 위해 쌀가루를 활용한 4종의 곰팡 이 균주별 무증자 쌀가루 개량 누룩을 제조해 효소활성 평가와 막걸리의 품질을 평가하였고, 기존 제조방법인 쌀 코지(입국)와 신규로 제조된 무증자 쌀가루 개량 누룩과의 품질을 평가하였다.

\section{재료 및 방법}

\section{실험 재료}

본 실험에 사용한 누룩, 코지 및 막걸리 제조용 쌀의 품종 은 전라남도 광양군에 위치한 광양주조공사에서 확보한 2017년산 한아름쌀을 실온에서 보관하면서 사용하였고, 조 제종국은 시중에 판매 중인 황국(황국조제종국, $\mathrm{YES}$ WINE, Boeun, Korea), 흑국(흑국조제종국, YES WINE, Boeun, Korea), 백국(백국조제종국, Chungmoo Fermentation, Ulsan, Korea), Penicillium candidum (SWUNG FD PCA-3(10U), Chr. Hansen SA, France) 균주 등 4종의 곰팡이 균주를 확보해 사용하였다.

\section{무증자 쌀가루 개량 누룩의 제조}

무증자 쌀가루 개량 누룩 제조는 분쇄한 쌀가루에 $100^{\circ} \mathrm{C}$ 의 온수 $30 \%$ 를 가하여 뜨거운 상태에서 반죽한 뒤, 반죽의 온도가 $30^{\circ} \mathrm{C}$ 에 도달 했을 때 4 종의 곰팡이 조제종국을 각각 $0.3 \%$ 씩 첨가해 2 차 반죽하였다. 반죽 후 누룩 제조 성형틀 에 넣고 성형해서 누룩 상자에 넣고 $30^{\circ} \mathrm{C}$, 습도 $85 \%$ 에서 48 시간 동안 1 차 배양 하였다. 2 차 배양은 누룩 상자의 뚜껑 을 제거하고 $25^{\circ} \mathrm{C}$, 습도 $85 \%$ 에서 누룩을 상자에 기대어 7 일간 배양한 다음 수분함량이 $10 \%$ 내외가 되게 건조시켰 다.

\section{쌀 코지(입국) 제조}

본 실험에 사용된 코지는 쌀 $1 \mathrm{~kg}$ 을 5시간 동안 물에 침지시킨 후 30 분간 증자하여 $30^{\circ} \mathrm{C}$ 로 냉각시킨 다음, 시판 백국(A kawachil)을 접종하고 $30^{\circ} \mathrm{C}$ 에서 3 일간 배양하여 효 소활성 측정 및 양조용 입국으로 사용하였다.

\section{누룩의 효소 활성 측정}

누룩의 전분 당화력 측정은 국세청기술연구소 주류분석 규정(15)에 따라 각 누룩에 $1 \% \mathrm{NaCl}$ 용액을 가하여 $30^{\circ} \mathrm{C}$ 에 서 3시간 침출시킨 액 또는 희석액을 시험용액으로 하고, $2 \%$ 전분액을 기질로 하였다. 기질용액 $50 \mathrm{~mL}$ 와 초산염완 충액 $30 \mathrm{~mL}$ 를 $55^{\circ} \mathrm{C}$ 수욕조에서 10 분간 방치하였다. 시험용 액 $10 \mathrm{~mL}$ 를 가해주고 1 시간 후 $0.5 \mathrm{~N} \mathrm{NaOH}$ 를 가하여 효소 작용을 중지시킨 다음 상온으로 방냉하고 물로 $100 \mathrm{~mL}$ 로 정용하였고, $100 \mathrm{~mL}$ 로 정용한 액의 $10 \mathrm{~mL}$ 와 시험용액 대신 
물을 취하여 동일하게 처리한 대조액 $10 \mathrm{~mL}$ 를 각각 취하여 환원 당을 측정하였다. 환원당 측정은 Fehling용액 $10 \mathrm{~mL}$, 물 $40 \mathrm{~mL}$, 포도당 표준용액 $10 \mathrm{~mL}$ 를 가해주고 끓여주면서 포도당표준용액으로 적정하였다. 황산동의 청색이 거의 없 어지면 메틸렌블루시액 4-5방울을 더 가하여 적정을 계속 하였고, 종말점은 메틸렌블루의 청색이 없어지는 점으로 이 때 소비된 포도당표준용액의 소비 $\mathrm{mL}$ 수를 $\mathrm{S}$ 라 하였다. 따로 Fehling용액 $10 \mathrm{~mL}$, 물 $40 \mathrm{~mL}$, 대조액 $10 \mathrm{~mL}$ 및 포도당 표준용액 $10 \mathrm{~mL}$ 를 사용하여 같은 방법으로 공시험을 행하 고 이때 소비된 포도당표준용액의 소비 $\mathrm{mL}$ 수를 $\mathrm{B}$ 로 하였 다.

Saccharogenic power(SP) $=\frac{(\mathrm{B}-\mathrm{S}) \times 2}{\mathrm{~W} \times 1}$

2 : Factor(20/10)로서 포도당표준용액 $(2 \mathrm{mg} / 1 \mathrm{~mL})$ 과 사 용된 표준용액 $10 \mathrm{~mL}$ 의 양에서 산출된 수치임

$\mathrm{W}$ : 시험용액 $10 \mathrm{~mL}$ 에 함유된 검체의 양 $(\mathrm{g})$

1 : 반응시간(시간).

누룩의 액화력 측정은 국세청기술연구소 주류분석 규정 (15)에 따라 각 누룩에 $0.5 \% \mathrm{NaCl}$ 용액을 가하여 실온 $\left(20^{\circ} \mathrm{C}\right.$ 이하)에서 3 시간 침출시켜 여과 후 효소용액으로 하고 $\mathrm{pH}$ 5.0 으로 보완한 $1 \%$ 녹말용액을 기질용액으로 하였다. 녹말 용액 $10 \mathrm{~mL}$ 를 $40^{\circ} \mathrm{C}$ 에서 예열한 후 효소용액 $0.5 \mathrm{~mL}$ 를 작용 시켜 작용혼합용액 중에서 $0.5-1$ 분마다 $0.1 \mathrm{~mL}$ 씩 요오드용 액 $10 \mathrm{~mL}$ 에 가하고 녹말요오드 반응색조를 분광광도계 (wavelength $670 \mathrm{~nm}$ )로 비색하여 투과율(T)이 66\%가 되는 반응시간을 구하고 비교용액은 물 $10 \mathrm{~mL}$ 에 효소액 $0.5 \mathrm{~mL}$ 를 가한 후 $0.1 \mathrm{~mL}$ 를 요오드용액에 가한 것을 투과율(T) $100 \%$ 로 하였다. 종점 전후의 반응시간을 비례 계산하여 $\mathrm{T}(66 \%)$ 가 될 때까지의 시간을 측정하였으며, 액화력은 다 음 식에 의해 계산하였다.

Dextrinogenic activity units $=10 \mathrm{~mL} \times 1 / 0.5$ (효소량)

$$
\times \frac{30}{\mathrm{~T}(66 \%) \text { 가 되는 반응시간 }}
$$

누룩의 단백질 분해력은 $\mathrm{So}(10)$ 의 방법을 참고하여 $\mathrm{pH}$ 를 5 로 조정한 $0.6 \%$ casein용액을 기질로, 누룩의 침출액을 효소액으로 하여 $40^{\circ} \mathrm{C}$ 에서 10 분간 반응 시켰다. 이 때 생산 되는 Folin 발색성 비단백성 물질의 양을 Folin 비색법(17) 으로 측정하여 발아 곡류 $1 \mathrm{~g}$ 이 1 분 동안 생성되는 tyrosine 을 $\mathrm{mg}$ 으로 나타내었다.

\section{막걸리 제조}

곰팡이 균주별 무증자 쌀가루 개량 누룩 첨가 막걸리의 제조는 쌀 $2 \mathrm{~kg}$ 을 수세하여 5 시간 물에 침지하고 2 시간 물 빼기 후 1 시간 동안 증자하고 $30^{\circ} \mathrm{C}$ 로 냉각하여 제조된 곰팡이 균주별 무증자 쌀가루 개량 누룩을 각각 $400 \mathrm{~g}$ 과 탁주효모(Takju yeast, Bioland, Ansan, Korea) $3 \mathrm{~g}$ 및 양조용 수 $3 \mathrm{~L}$ 를 첨가해 $23-25^{\circ} \mathrm{C}$ 에서 12 일간 발효 시켰다. 쌀 코지 (A kawachii) 첨가 막걸리 제조는 곰팡이 균주별 무증자 쌀가루 개량 누룩 첨가 막걸리의 고두밥 제조 방법과 동일 한 방법으로 제조하고 쌀 코지(A kawachii) $400 \mathrm{~g}$ 과 탁주효 모(Takju yeast, Bioland) $3 \mathrm{~g}$ 및 양조용수 $3 \mathrm{~L}$ 를 첨가해 23-2 $5^{\circ} \mathrm{C}$ 에서 12 일간 발효 시켰다.

\section{$\mathrm{pH}$, 총산 및 환원당 함량 측정}

$\mathrm{pH}$ 는 발효 중인 술덧 여액 $20 \mathrm{~mL}$ 를 취하여 $\mathrm{pH}$ meter(HM-40X, DKK-TOA, Tokyo, Japan)를 사용해 측정하 였고, 적정 산도는 시료 $1 \mathrm{~mL}$ 에 증류수 $9 \mathrm{~mL}$ 를 가한 후 혼합하여 희석시킨 뒤 $1 \%$ phenolphthalein 용액을 지시약으 로 하여 $0.1 \mathrm{~N} \mathrm{NaOH}$ 용액으로 중화 적정시킨 후 0.009 를 곱하여 lactic acid로 환산하였다. 환원당 함량 변화는 시료 를 $10 \mathrm{~mL}$ 를 Somogyi변법(18)에 의해 정량하여 glucose 함 량으로 표시하였다.

\section{에탄올 함량 측정}

에탄올 함량은 시료 $100 \mathrm{~mL}$ 을 취하여 증류수 약 $30 \mathrm{~mL}$ 을 혼합하고, $80 \mathrm{~mL}$ 을 증류한 다음 증류수로 $100 \mathrm{~mL}$ 이 되게 정용한 후 주정계를 사용하여 값을 읽고, 온도측정을 한 후 Gay-Lussak의 주정환산표(19)로 주정분을 결정하였다.

\section{관능평가}

관능평가는 순천대학교 생명윤리심의위원회 심의 결과 승인을 받은 후 시행되었다(승인번호: 1040173-201809HR-033-04). 막걸리의 관능평가는 10 명의 패널을 선정하여 향(flavor), 색(color), 맛(taste), 전체적인 기호도(overall preference)를 9단계 평가법으로 실시하였다. 채점 기준은 아주 좋다; 9점, 보통이다; 5점, 아주 나쁘다; 1점으로 하였 고, 2 시간 간격으로 시료의 번호를 바꾸어 같은 panel로 3 회 반복하였으며 각 반복 시 가장 높은 점수와 가장 낮은 점수를 제외하고 평균 득점을 구하였다.

\section{통계처리 방법}

본 실험은 독립적으로 3 회 이상 반복 실시하여 실험결과 를 SPSS 통계분석 프로그램을 이용하여 각 실험군간 평균 치와 표준편차를 계산하였고, Duncan's multiple range test 에 의해 평균치간의 유의성을 검정하였다. 또한 독립된 두 집단의 평균값 비교는 두 표본 t-검정(two sample t-test)을 이용하여 분석하였다. 


\section{결과 및 고찰}

누룩의 효소활성( $\beta$-amylase 활성, $a$-amylase 활성, protease 활성도)

일반적으로 쌀을 이용해 제조되는 누룩의 제조 방법을 보면 쌀을 세척하고 불려 증기를 이용해 증자하여 고두밥을 제조하고 냉각하여 백국 $(A$ kawachii $)$ 으로 2-3일간 띄어 제 조되며 그렇게 만들어진 누룩을 코지라고 부르고 있다(20). 현재 양조업체는 이러한 코지 제조 방법이 제조 공정이 복잡하고, 고도의 기술력을 요구하고 있어 제조에 많은 어 려움을 겪고 있다. 따라서 쌀을 이용한 누룩의 제조 방법을 현장에서 손쉽고, 공정이 간편한 제조기술을 개발해야 하 는 필요성이 있다. 본 연구에서는 이러한 어려움을 해결하 기 위해 고두밥 제조 과정을 생략해서(Fig. 1) 누룩을 제조 하고 기존 제조방법인 쌀 코지와 신규로 제조된 무증자 쌀가루 개량 누룩과의 품질을 평가하였다.

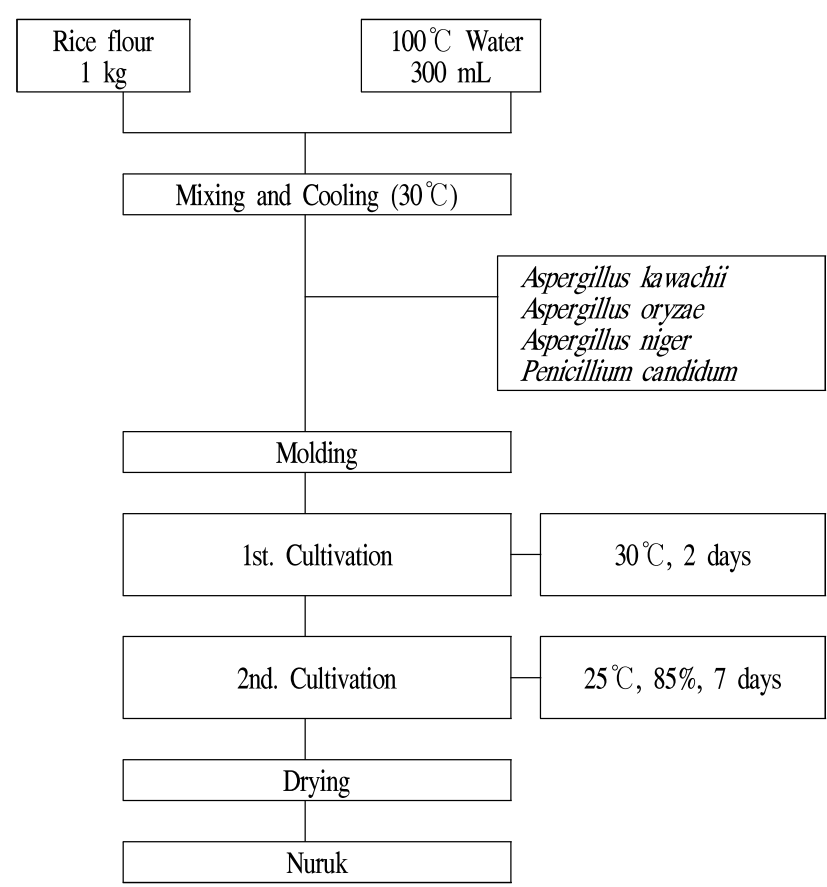

Fig. 1. Process for the preparation of non-steamed rice flour Nuruk by various fungal strains.

A kawachii 곰팡이로 제조한 쌀 코지와 $A$ kawachii, $A$ oryzae, $A$ niger와 P. candidum 4종의 곰팡이로 제조한 무증 자 쌀가루 개량 누룩의 $\beta$-amylase 활성, a-amylase 활성 및 protease 활성도를 측정한 결과는 Table 1 과 같다. $\beta$-amylase 활성은 코지나 누룩 $1 \mathrm{~g}$ 이 가용성 전분 $1 \mathrm{~g}$ 에 작용하여 생성된 포도당 함량을 가용성 전분 $1 \mathrm{~g}$ 에 대한 백분율로 표기하고 이 값에 효소액의 희석배수를 곱한 값으로 나타낸 다. 국세청기술연구소 주류분석규정에 막걸리 제조에 적합 한 누룩의 $\beta$-amylase 활성은 $300 \mathrm{sp}$ 이상으로 지정되어 있다
(20). A kawachii 곰팡이로 제조한 쌀 코지의 $\beta$-amylase 활성은 $2,884.51 \mathrm{SP} / \mathrm{g}$ 였고, 각각 $A$ kawachii, $A$ oryzae와 P. candidum 곰팡이 균주로 제조된 무증자 쌀가루 개량 누룩의 $\beta$-amylase 활성은 2,958.28-3,697.85 SP/g로 더 높은 활성을 보였다. 그 중 $A$ oryzae 곰팡이 균주를 첨가한 쌀가 루 개량 누룩의 $\beta$-amylase 활성이 $3,697.85 \mathrm{SP} / \mathrm{g}$ 로 가장 높은 활성을 보였고, $A$ niger 곰팡이균주를 첨가한 쌀가루 개량누룩은 2,563.84 SP/g로 $A$ kawachii 곰팡이로 제조한 쌀 코지의 $\beta$-amylase 활성 보다 낮게 나타났다.

a-amylase 활성 또한 $A$ kawachii 곰팡이로 제조한 쌀 코지 보다 $A$ kawachii, $A$ oryzae와 P. candidum 곰팡이 균주로 제조된 무증자 쌀가루 개량 누룩이 높은 활성을 보였고, 그 중 P. candidum 곰팡이를 첨가한 쌀가루 개량누 룩이 111.67 A.U로 가장 높은 값으로 측정되었다. $A$ niger 곰팡이균주를 첨가한 쌀가루 개량누룩은 53.71 A.U로 $A$ kawachii 곰팡이로 제조한 쌀 코지와 동일한 값으로 측정되 었다.

Protease 활성도는 P. candidum 곰팡이를 첨가한 쌀가루 개량누룩과 $A$ oryzae 곰팡이 균주를 첨가한 쌀가루 개량 누룩이 33.23 tyrosine $\mathrm{mg} / \mathrm{min}$ 와 24.76 tyrosine $\mathrm{mg} / \mathrm{min}$ 로 A kawachii 곰팡이로 제조한 쌀 코지의 20.43 tyrosine $\mathrm{mg} / \mathrm{min}$ 보다 높은 값을 나타냈다. A niger 곰팡이균주를 첨가한 쌀가루 개량누룩의 경우 15.55 tyrosine $\mathrm{mg} / \mathrm{min}$ 로 A kawachii 곰팡이로 제조한 쌀 코지 보다 낮은 값으로 측정되었고, $A$ kawachii 곰팡이 균주로 제조된 무증자 쌀가 루 개량 누룩은 동일한 값으로 확인되었다.

\section{곰팡이 균주별 무증자 쌀가루 개량 누룩 첨가 막걸리의 품질 특성 \\ $\mathrm{pH}$ 및 적정산도}

막걸리의 $\mathrm{pH}$ 는 발효가 진행되는 과정에서 발효의 정도 또는 과정을 확인할 수 있게 해주는 지표이다(21). 또한 막걸리의 품질에 중요한 영향을 주는 지표인 적정 산도는 막걸리의 풍미와 보전성에 큰 영향을 미치는 중요한 성분 중 하나이다(22). 따라서 곰팡이 균주별 무증자 쌀가루 개량 누룩 첨가 막걸리의 $\mathrm{pH}$ 와 적정 산도를 측정한 결과는 Fig. 3,4 와 같다. 발효 기간에 따른 쌀가루 개량누룩을 첨가해 제조한 막걸리의 $\mathrm{pH}$ 는 발효 기간이 경과함에 따라 전체 시료구에서 $\mathrm{pH}$ 가 상승하는 것을 확인할 수 있었다. 시료구 별 $\mathrm{pH}$ 의 경우 발효 2 일째 $A$ oryzae 쌀가루 개량 누룩 첨가 막걸리의 $\mathrm{pH}$ 는 4.49로 가장 높았고, $A$ kawachii 쌀가루 개량 누룩 첨가 막걸리가 3.59로 가장 낮게 나타났으며, 발효 완료되는 지점인 12 일째에도 $A$ kawachii 쌀가루 개량 누룩 첨가 막걸리의 $\mathrm{pH}$ 가 가장 높았고, 다른 3 개의 시료구 와 비교해 $\mathrm{pH}$ 값의 유의적 차이가 크게 나타났다. 막걸리의 적정 산도는 발효기간이 경과함에 따른 상승하는 경향을 보였다. 막걸리 제조에서 정상적인 발효가 진행 될 경우 
Table 1. Enzymic activity of rice Koji and non-steamed rice flour Nuruk by various fungal strains

\begin{tabular}{cccccc}
\hline \multirow{2}{*}{ Enzymic activity } & \multicolumn{2}{c}{$A$ kawachii } & A oryzae & A niger & P. candidum \\
\cline { 2 - 6 } & RK $^{1)}$ & RFN & RFN & RFN & RFN \\
\hline Saccharogenic activity (SP/g) & $2,884.51 \pm 296.11^{2) b 3)}$ & $2,958.28 \pm 312.39^{\mathrm{b}}$ & $3,697.85 \pm 147.91^{\mathrm{a}}$ & $2,563.84 \pm 351.88^{\mathrm{c}}$ & $3,155.50 \pm 215.88^{\mathrm{ab}}$ \\
Dextrinogenic activity (A.U) & $53.71 \pm 3.21^{\mathrm{c}}$ & $57.87 \pm 4.01^{\mathrm{c}}$ & $75.48 \pm 6.95^{\mathrm{b}}$ & $53.71 \pm 2.32^{\mathrm{c}}$ & $111.67 \pm 8.43^{\mathrm{a}}$ \\
\hline Proteolytic activity (tyrosine $\mathrm{mg} / \mathrm{min}$ ) & $20.43 \pm 2.2^{\mathrm{b}}$ & $20.42 \pm 3.2^{\mathrm{bc}}$ & $24.76 \pm 3.6^{\mathrm{b}}$ & $15.55 \pm 1.8^{\mathrm{c}}$ & $33.23 \pm 4.4^{\mathrm{a}}$ \\
\hline
\end{tabular}

${ }^{1}$ RK, Rice Koji ; RFN, Non-heating rice flour Nuruks.

${ }^{2)}$ All values are meanr $\pm \mathrm{SD}$.

${ }^{3)}$ Values with different superscript letters in the same row are significantly different at $\mathrm{p}<0.05$ by Duncan's multiple range test $(\mathrm{a}>\mathrm{b}>\mathrm{c})$.

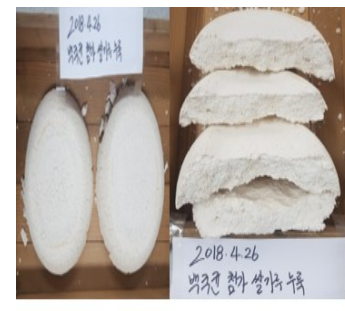

AKN

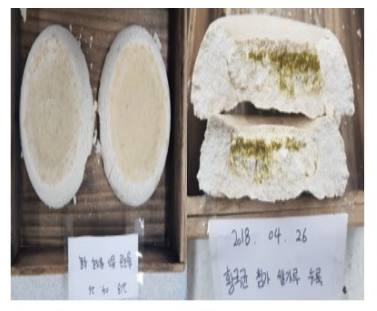

AON

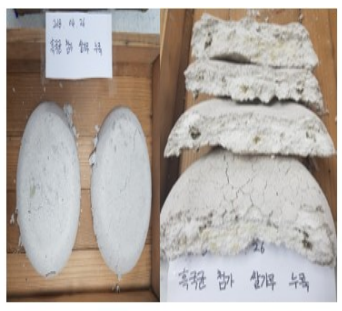

ANI

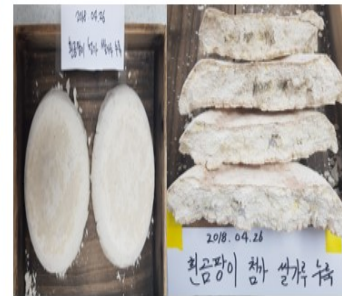

PCN

Fig. 2. Photographs of non-steamed rice flour Nuruk by various fungal strains.

AKN, $A$ kawachii rice flour Nuruk; AON, $A$ oryzae rice flour Nuruk; ANN, $A$ niger rice flour Nuruk; PCN, P. candidum rice flour Nuruk

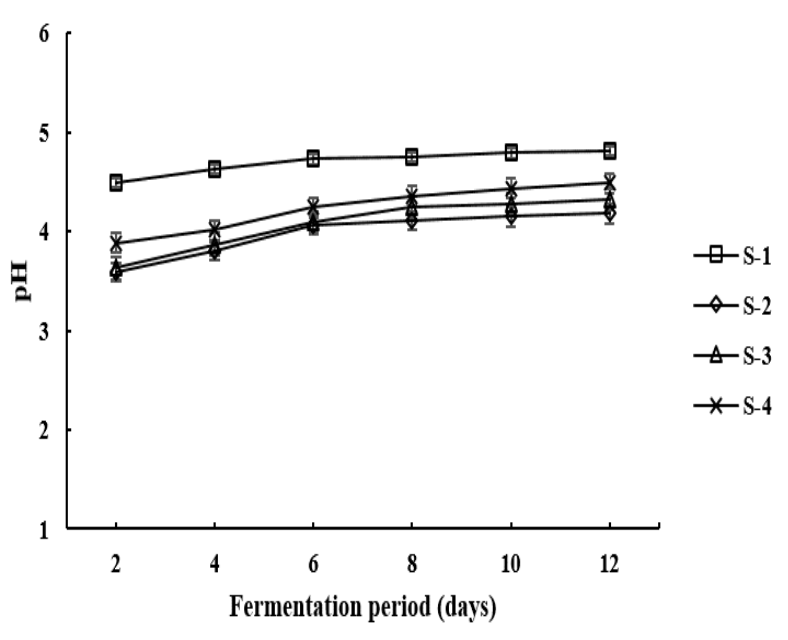

Fig. 3. Changes in $\mathrm{pH}$ of Makgeolli made with non-steamed rice flour Nuruk by various fungal strains during fermentation period.

S-1, Makgeolli made with $A$ oryzae rice flour Nuruk (AON); S-2, Makgeolli made with $A$ kawachii rice flour Nuruk (AKN) ; S-3, Makgeolli made with $A$ niger rice flour Nuruk (ANN) ; S-4, Makgeolli made with P. candidum rice flour Nuruk (PCN).

각종 유기산들이 생성되어 적정 산도 값이 상승한다고 보고 되어 있다(23). 본 연구에서도 발효 기간이 경과함에 따라 적정 산도 값이 상승하는 경향을 보여 정상적인 발효가 진행 되었다고 판단된다. 시료구별 막걸리의 산도 변화는 발효 2일째 P. candidum 쌀가루 개량누룩 첨가 막걸리의 산도가 $0.34 \%$ 로 가장 낮게 나타났으나 발효가 완료되는 지점인 12 일째에는 $0.6 \%$ 로 다른 시료구와 비슷한 함량을 보였고, $A$ oryzae 쌀가루 개량 누룩 첨가 막걸리 시료구가 $0.53 \%$ 로 가장 낮은 함량을 보였다.

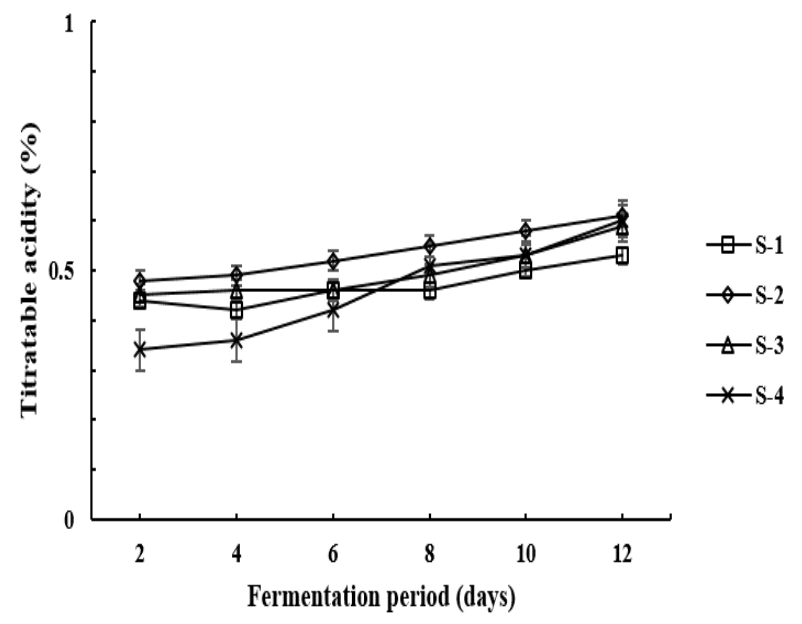

Fig. 4. Changes in titratable acidity of Makgeolli made with non-steamed rice flour Nuruk by various fungal strains during fermentation period.

S-1, Makgeolli made with $A$ oryzae rice flour Nuruk (AON) ; S-2, Makgeolli made with $A$ kawachii rice flour Nuruk (AKN) ; S-3, Makgeolli made with $A$ niger rice flour Nuruk (ANN) ; S-4, Makgeolli made with $P$. candidum rice flour Nuruk (PCN).

\section{환원당 및 에탄올}

곰팡이 균주별 무증자 쌀가루 개량 누룩 첨가 막걸리의 환원당 및 에탄올 함량을 측정한 결과는 Fig. 5,6과 같다. 막걸리의 발효 중 환원당 함량의 증가와 감소는 막걸리의 산미, 감칠맛 그리고 에탄올 생성에 중요한 영향을 미치는 성분이다(24). 발효 2 일차 환원당 함량은 $A$ oryzae 쌀가루 개량 누룩 첨가 막걸리 시료구와 $A$ kawachii 쌀가루 개량 
누룩 첨가 막걸리 시료구에서 가장 높게 나타났다. 발효 기간에 따른 환원당 함량은 발효 2 일째부터 4 일째까지는 소량 감소하는 경향을 보였고 4 일째부터 8 일째까지는 소량 증가하는 모습을 보였으며 8 일째 이후로는 감소하는 것으 로 나타났다. 막걸리의 경우 병행복발효주로써 전분의 당 화와 에탄올 발효가 동시에 일어나는 과정으로 제조된다 (25). 본 연구에서는 막걸리 담금 후 발효 4 일째부터 8 일째 까지 환원당의 함량이 소량으로 증가하는 경향을 보여 곰팡 이 균주별 무증자 쌀가루 개량 누룩의 효소 활성이 발효 8 일째까지 유지 되었다는 것을 확인할 수 있었다.

막걸리의 에탄올 함량은 술의 품질과 생산 수율을 결정 하는 중요한 요인 중 하나이다. 또한 에탄올 발효는 당을 에탄올과 $\mathrm{CO}_{2}$ 로 분해한 것이며 담금 후 기포 발생 유무로 에탄올 발효가 진행됨을 확인할 수 있다(26). 발효기간에 따른 에탄올 함량 변화의 경우 발효 2 일째 $A$ oryzae 쌀가루 개량 누룩 첨가 막걸리와 $A$ niger 곰팡이균주를 첨가한 막걸리가 $11.7 \%$ 와 $11.2 \%$ 로 높게 나타났고, $A$ kawachii 쌀 가루 개량 누룩 첨가 막걸리와 P. candidum 쌀가루 개량누 룩 첨가 막걸리는 $8.8 \%$ 와 $8.1 \%$ 로 $A$ oryzae 쌀가루 개량 누룩 첨가 막걸리와 $A$ niger 쌀가루 개량 누룩 첨가 막걸리 에 비해 상대적으로 낮게 나타났다. 하지만 발효가 진행됨 에 따라 발효 12 일째에는 전체 시료구가 $16.1-16.4 \%$ 로 유의 적 차이를 보이지 않았다. 본 연구에서 확인된 쌀가루 개량 누룩을 이용해 제조한 막걸리의 에탄올 생산 수율은 매우 높은 수준 이었으며, 추가 연구로 쌀 코지를 첨가해 제조한 막걸리와 곰팡이균주별 쌀가루 개량누룩 첨가 막걸리와의 에탄올 생산 수율을 평가해 누룩의 품질을 비교 평가 하였 다.

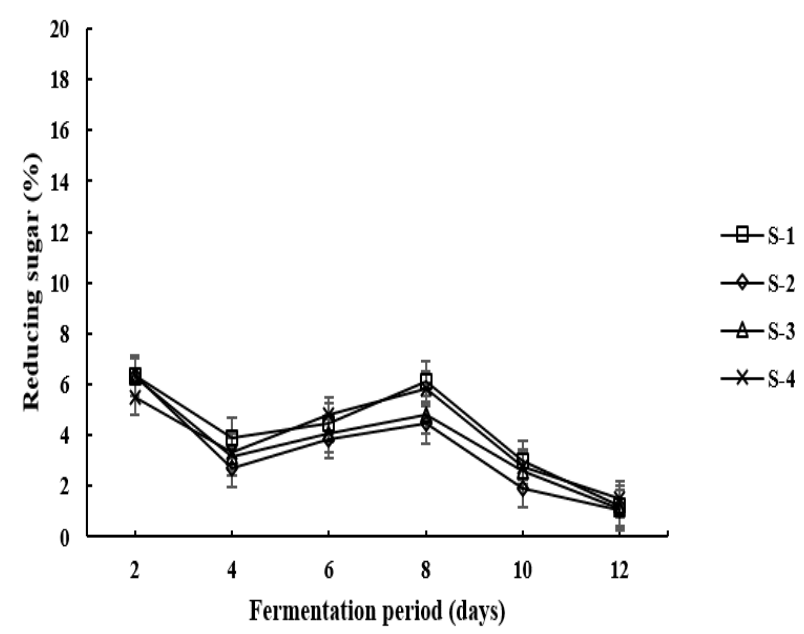

Fig. 5. Changes in reducing sugar content of Makgeolli made with non-steamed rice flour Nuruk by various fungal strains during fermentation period.

S-1, Makgeolli made with $A$ oryzae rice flour Nuruk (AON); S-2, Makgeolli made with $A$ kawachii rice flour Nuruk (AKN) ; S-3, Makgeolli made with $A$ niger rice flour Nuruk (ANN) ; S-4, Makgeolli made with P. candidum rice flour Nuruk (PCN).

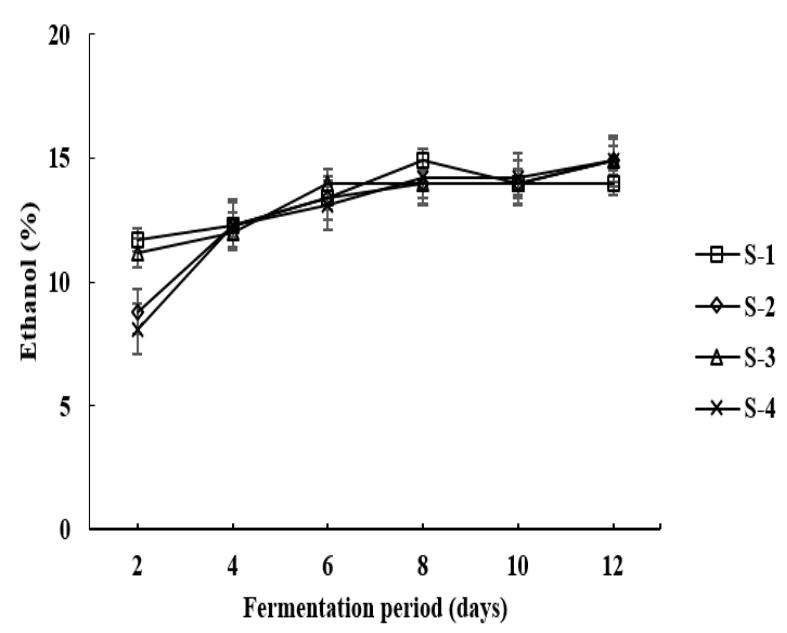

Fig. 6. Changes in ethanol content of Makgeolli made with non-steamed rice flour Nuruk by various fungal strains during fermentation period.

S-1, Makgeolli made with $A$ oryzae rice flour Nuruk (AON) ; S-2, Makgeolli made with $A$ kawachii rice flour Nuruk (AKN) ; S-3, Makgeolli made with $A$ niger rice flour Nuruk (ANN) ; S-4, Makgeolli made with P. candidum rice flour Nuruk (PCN).

\section{관능평가}

곰팡이 균주별 무증자 쌀가루 개량 누룩을 첨가한 막걸 리의 관능 평가 결과는 Table 2 와 같다. 색은 P. candidum 쌀가루 개량누룩 첨가 막걸리가 7.67 로 가장 높은 기호도를 보였고 $A$ oryzae 쌀가루 개량 누룩 첨가 막걸리가 4.67로 가장 낮은 기호도를 나타냈다. 향 그리고 맛 또한 $P$. candidum 쌀가루 개량누룩 첨가 막걸리에서 가장 높은 기 호도를 보였으나 유의적 차이를 보이지 않았다. 전체적인 호도는 P. candidum 쌀가루 개량누룩 첨가 막걸리가 5.78로 가장 높은 기호도를 보였고 유의적 차이를 나타냈다. 다음 으로는 $A$ kawachii 쌀가루 개량 누룩 첨가 막걸리가 4.44로 높은 기호도를 나타냈다. 본 연구에서 사용한 P. candidum 곰팡이 균주는 주로 치즈 제조 시에 사용되는 균주이며 $(27,28)$ 일반적으로 현재 쌀 누룩 제조 시에는 종균으로 사용되지 않은 균주이다. 하지만 전통누룩에서 Penicillium 균주가 확인되었다는 보고(10) 내용을 바탕으로 본 연구의 목적인 다양한 곰팡이 균주를 사용해 무증자 쌀가루 개량 누룩 제조에 적합한 곰팡이 균주를 찾고자 연구를 수행한 결과 P. candidum 곰팡이 균주를 첨가해 제조한 누룩의 효소 활성이 높게 나타났고, 그 누룩을 첨가해 제조된 막걸 리의 기호도 또한 품질이 우수한 것으로 나타나 의미 있는 결과로 판단되었으며, 기존 쌀 코지를 활용해 제조되는 막 걸리와의 품질 비교 필요성이 있을 것으로 판단되어 품질 비교 연구를 추가로 진행하였다.

\section{쌀 코지 첨가 막걸리와 P. candidum 쌀가루 개량누룩} 첨가 막걸리의 품질 특성

위의 곰팡이 균주별 무증자 쌀가루 개량누룩의 품질 평 가에서 효소 활성이 높게 나타났고, 막걸리의 기호도 또한 
Table 2. The sensory evaluation of Makgeolli made with non-steamed rice flour Nuruk by various fungal strains

\begin{tabular}{ccccc}
\hline Component & Color & Flavor & Taste & Overall preference \\
\hline S- $1^{1)}$ & $4.67 \pm 2.15^{2) \mathrm{b} 3)}$ & $5.33 \pm 1.32^{\mathrm{ab}}$ & $3.56 \pm 2.15^{\mathrm{b}}$ & $3.67 \pm 1.69^{\mathrm{b}}$ \\
S-2 & $5.44 \pm 2.01^{\mathrm{b}}$ & $5.00 \pm 1.76^{\mathrm{ab}}$ & $4.22 \pm 2.22^{\mathrm{b}}$ & $4.44 \pm 1.33^{\mathrm{b}}$ \\
S-3 & $5.89 \pm 1.80^{\mathrm{b}}$ & $4.33 \pm 1.72^{\mathrm{b}}$ & $3.67 \pm 1.81^{\mathrm{b}}$ & $3.56 \pm 1.51^{\mathrm{b}}$ \\
S-4 & $7.67 \pm 2.47^{\mathrm{a}}$ & $6.48 \pm 2.19^{\mathrm{a}}$ & $6.67 \pm 2.18^{\mathrm{a}}$ & $5.78 \pm 1.09^{\mathrm{a}}$ \\
\hline
\end{tabular}

${ }^{1)}$ S-1, Makgeolli made with $A$ oryzae rice flour Nuruk

S-2, Makgeolli made with $A$ kawachii rice flour Nuruk

S-3, Makgeolli made with $A$ niger rice flour Nuruk

S-4, Makgeolli made with P. candidum rice flour Nuruk

${ }^{2)}$ All values are meant \pm SD.

${ }^{3}$ Values with different superscript letters in the same column are significantly different at $p<0.05$ by Duncan's multiple range test $(a>b)$.

품질이 우수한 것으로 나타난 P. candidum 쌀가루 개량누룩 첨가 막걸리와 기존에 쌀 코지를 첨가해 제조되는 막걸리와 의 품질을 비교해 본 연구에서 개발된 P. candidum 쌀가루 개량누룩의 경쟁력을 파악하고자 하였다. 따라서 쌀 코지 첨가 막걸리와 P. candidum 쌀가루 개량누룩 첨가 막걸리의 발효 12 일째 $\mathrm{pH}$, 적정산도 환원당 및 에탄올 함량을 측정한 결과는 Table 3 과 같다. $\mathrm{pH}$ 의 경우 $P$. candidum 쌀가루 개량 누룩 첨가 막걸리가 4.35 로 쌀 코지 첨가 막걸리의 4.23 보다 높았고, 적정산도와 환원당 함량 또한 $P$. candidum 쌀가루 개량누룩 첨가 막걸리가 높게 나타났다. 막걸리의 품질을 평가 하는데 영향력이 가장 크게 미치는 에탄올 함량의 경우 쌀 코지 첨가 막걸리는 $12.80 \%$ 였고, $P$. candidum 쌀가루 개량누룩 첨가 막걸리는 $15.10 \%$ 로 $P$. candidum 쌀가루 개량누룩 첨가 막걸리가 $2.30 \%$ 가 더 높게 나타나 에탄올 생산 수율에서 경쟁력이 있는 것으로 확인되 었다.

쌀 코지 첨가 막걸리와 P. candidum 쌀가루 개량누룩 첨가 막걸리의 발효 종료 후 관능평가를 실시한 결과는 Table 4와 같다. 색 및 향의 기호도는 쌀 코지 첨가 막걸리가 $7.0,6.6$ 으로 P. candidum 쌀가루 개량누룩 첨가 막걸리의 $6.7,5.9$ 보다 높은 기호도를 보였으나, 맛과 전체적인 기호 도의 경우 P. candidum 쌀가루 개량누룩 첨가 막걸리가7.0, 6.9로 쌀 코지 첨가 막걸리의 $6.6,6.6$ 보다 높은 기호도

Table 3. Quality characteristics of Makgeolli made with rice Koji and $P$. candidum rice flour Nuruk

\begin{tabular}{ccccc}
\hline Component & K-1 $1^{1)}$ & $\mathrm{S}-4$ & T-value & P-value \\
\hline $\mathrm{pH}$ & $4.23 \pm 0.01^{2)}$ & $4.35 \pm 0.02$ & $\left.-12.728^{* * 3}\right)$ & .000 \\
Titratable acidity (\%) & $0.42 \pm 0.02$ & $0.48 \pm 0.01$ & $-5.477^{* *}$ & .005 \\
Reducing sugar (\%) & $4.08 \pm 0.1$ & $4.14 \pm 0.27$ & -.354 & .742 \\
Ethanol (\%) & $12.80 \pm 0.17$ & $15.10 \pm 0.12$ & $-15.254^{* * *}$ & .000 \\
\hline
\end{tabular}

${ }^{11} \mathrm{~K}-1$, Makgeolli made with rice Koji ; S-4, Makgeolli made with $P$. candidum rice flour Nuruk

${ }^{2)}$ All values are mean $\pm \mathrm{SD}$

3)** $\mathrm{p}<0.05, \stackrel{ }{* * *} \mathrm{p}<0.005$.
를 보였다. 따라서 본 연구에서 신규로 제조된 P. candidum 곰팡이를 활용한 무증자 쌀가루 개량누룩의 경우 국내 약. 탁주 시장에 충분한 활용 가치가 있을 것으로 판단된다.

Table 4. The sensory evaluation of Makgeolli made with rice Koji and $P$. candidum rice flour Nuruk

\begin{tabular}{ccccc}
\hline Component & K-1 $1^{1)}$ & S-4 & T-value & P-value \\
\hline Color & $7.0 \pm 1.49^{2)}$ & $6.7 \pm 1.16$ & .502 & .622 \\
Flavor & $6.6 \pm 1.07$ & $5.9 \pm 1.79$ & $1.059^{* 3)}$ & .303 \\
Taste & $6.6 \pm 1.17$ & $7.0 \pm 1.25$ & $-.739^{*}$ & .470 \\
Overall perception & $6.6 \pm 1.17$ & $6.9 \pm 1.20$ & -.566 & .578 \\
\hline
\end{tabular}

${ }^{1)} \mathrm{K}-1$, Makgeolli made with rice Koji ; S-4, Makgeolli made with $P$. candidum rice flour Nuruk

${ }^{2)}$ All values are mean $\pm \mathrm{SD}$.

${ }^{3)^{*}} \mathrm{p}<0.5$.

\section{요 약}

본 연구에서는 쌀을 이용한 누룩의 제조 방법을 현장에 서 손쉽고, 공정이 간편한 제조기술을 개발하기 위해 무증 자 쌀가루 개량 누룩을 개발하고자 하였다. 기존의 쌀 코지 와 무증자 쌀가루 개량 누룩의 효소활성을 비교한 결과 $\beta$-amylase 활성은 $A$ oryzae 곰팡이 균주를 첨가한 쌀가루 개량 누룩(AON)의 활성이 $3,697.85 \mathrm{SP} / \mathrm{g}$ 로 가장 높은 활성 을 보였고, a-amylase 활성과 protease 활성을 측정한 결과는 P. candidum 곰팡이를 첨가한 쌀가루 개량누룩 $(\mathrm{PCN})$ 이 111.67 A.U과 33.23 tyrosine $\mathrm{mg} / \mathrm{min}$ 로 가장 높은 활성을 보였다. 곰팡이 균주별 무증자 쌀가루 개량누룩 첨가 막걸 리의 품질을 평가한 결과 $\mathrm{pH}$ 의 경우 발효 완료되는 지점인 12일째 $A$ kawachii 쌀가루 개량 누룩(AKN) 첨가 막걸리의 $\mathrm{pH}$ 가 가장 높았고, 막걸리의 적정산도는 4 개 시료구 모두 비슷한 값을 보였다. 막걸리의 환원당 함량은 전체 시료구 에서 발효 기간이 지남에 따라 8 일차까지는 소량 증가하는 모습을 보였으며 8 일차 이후로는 감소하는 것으로 나타났 고, 에탄올 함량은 발효 12일째 전체 시료구가 $16.1-16.4 \%$ 로 유의적 차이를 보이지 않았다. 곰팡이 균주별 무증자 쌀가루 개량누룩 첨가 막걸리의 관능평가 결과는 전체적인 기호도에서 $\mathrm{PCN}$ 첨가 막걸리가 5.78로 가장 높은 기호도를 보였고 유의적 차이를 나타냈다. 이후 $\mathrm{PCN}$ 첨가 막걸리와 기존에 쌀 코지를 첨가해 제조되는 막걸리와의 품질을 비교 하였다. $\mathrm{pH}$ 의 경우 발효 12 일째 $A$ kawachii 쌀 코지(RK) 첨가 막걸리는 4.23 의 값을 보인 반면 $\mathrm{PCN}$ 첨가 막걸리의 경우 4.35 로 높은 값을 보였다. 산도 및 환원당 함량 역시 $\mathrm{PCN}$ 첨가 막걸리가 $0.48 \%, 4.14 \%$ 로 높은 값을 나타냈으며, 막걸리 품질에 중요한 요소인 에탄올 함량 역시 발효 종료 시점에서 $\mathrm{RK}$ 첨가 막걸리가 $12.80 \%$ 이었으나, $\mathrm{PCN}$ 첨가 막걸리가 $15.10 \%$ 로 더 높은 에탄올 생산 수율을 보였고, 
관능평가에서도 전체적인 기호도의 경우 $\mathrm{PCN}$ 첨가 막걸리 가 6.9 로 $\mathrm{RK}$ 첨가 막걸리의 6.6 보다 높은 기호도를 보였다. 따라서 신규 제조 방법으로 제조된 P. candidum 곰팡이를 첨가한 무증자 쌀가루 개량 누룩이 막걸리 제조에 충분한 활용 가치가 있을 것으로 판단된다.

\section{감사의 글}

본 연구는 농촌진흥청 산학연협력 광역화사업 전남농업 기술원 쌀산학연협력단의 연구비 지원(2018-0124)을 받아 실행한 결과의 일부로 이에 감사드립니다.

\section{References}

1. Oh SK, Kim DJ, Ryu SJ, Chun A, Yoon MR, Choi IS, Hong HC, Kim YK (2011) Quality characteristics of Korean traditional wine using Seolgaengbyeo for brewing rice. J Korean Soc Food Sci Nutr, 40, 1189-1194

2. Lee TJ, Hwan DY, Lee CY, Son HJ (2009) Changes in yeast cell number, total acid and organic acid during production and distribution processes of Makgeolli, traditional alcohol of Korea. Korean J Microbiol, 45, 391-396

3. Yang JY, Lee KH (1996) Shelf-life and microbiological study of Sansung takju. Korean J Food Sci Technol, 28, 779-785

4. Jeong JW, Park KJ, Kim MH, Kim DS (2006) Quality characteristics of Takju fermentation by addition of Chestnut peel powder. Korean J Food Preserv, 13, 329-336

5. Jeong SC, Yu MJ, Cho YK, Lee JS (2003) Characteristics of traditional wine-Koji and isolation of fungi. J Natural Sci, 13, 73-82

6. Han EH, Lee TS, Noh BS, Lee DS (1997) Quality characteristics in mash of Takju prepared by using different Nuruk during fermentation. Korean J Food Sci Technol, 3, 555-562

7. Yi HC, Moon SH, Park JS, Jung JW, Hwang KT (2010) Volatile compounds in Liquor distilled from msg produced using Koji or Nuruk under reduced or atmospheric pressure. J Korean Soc Food Sci Nutr, 6, 880-886

8. Han EH, Lee TS, Noh BS, Lee DS (1997) Volatile flavor components in Mash of Takju perpared by using different Nuruk Korean J Food Sci Technol, 3, 563-570
9. Yu TS, Kim J, Kim HS, Hyun JS, Ha HP, Park MG. (1996) Bibliographical study on microorganisms of Nuruk (Until 1945). J Korean Soc Food Nutr, 25, 170-179

10. Yu TS, Kim J, Kim HS, Hyun JS, Ha HP, Park MG. (1998) Bibliographical study on microorganisms of traditional Korean Nuruk (Since 1945). J Korean Soc Food Nutr, 27, 789-799

11. Choi SH, Lee SJ (2014) Quality characteristics of Korean wheat bread prepared with substitutions of naturally fermented rice starters. Culinary Science \& Hospitality Research, 20, 100-119

12. Bea KH, Ryu HY, Kwun IS, Kwon CS, Sohn HY (2007) Optimization of thickness and maturation period of Andong-Soju Nuruk for fermentation of Andong-Soju. Korean J Microbiol Biotechnol, 35, 231-237

13. Lee MH, Oh MS (2006) Quality characteristics of cookies with brown rice flour. Korean J Food Culture, 21, 685-694

14. Kim MY (2007) Quality characteristics fat-suvstituted rice cookies prepared from rice with different farming condition. MS Thesis, Chonnam National University, Korea

15. NTS Liquors Licence Aid Center (2010) Analysis of alcoholic beverages. National Tax Service, Seoul, Korea, p $12-16$

16. So MH (1999) Characteristics of modified Nuruk made by inoculation of traditional Nuruk microorganisms. Korean J Food \& Nutr, 12. 219-225

17. Folin O, Ciocalteau V (1927) On tyrosine and tryptophane determination in protein. J Biol Chem, 73, 627

18. Hatakana C, Kobara Y (1990) Determination of glucose by a modification of Somogyi-Nelson method. J Korean Soc Agric Chem, 44, 2943-2949

19. NTS Liquors Licence Aid Center (2010) Analysis of alcoholic beverages. National Tax Service, Seoul, Korea. p. 40

20. NTS Liquors Licence Aid Center (2010) Analysis of alcoholic beverages. National Tax Service, Seoul, Korea, p. 79

21. Lee SJ, Kim JH, Jung YW, Park SY, Shin WC, Park CS, Hong SY, Kim GW (2011) Composition of organic acids and physiological functionality of commercial Makgeolli. Korean J Food Sci Technol, 43, 206-212

22. Yang HS, Eun JB (2011) Fermentation and sensory characteristics of Korean traditional fermented Liquor (Makgeolli) added with Citron (Citrus hunos SIEB ex TANAKA) Juice. Koean J Food Sci Technol, 43, 438-445 23. Song JC, Park HJ, Shin WC (1997) Change of Takju 
qualities by addition of cyclodextrin during the brewing and aging. Korean J Food Sci Technol, 29, 895-900

24. Lee JW, Park JW (2010) Quality characteristics of Makgeolli during separation storage methods. Food Eng Progress, 14, 346-353

25. Lee H, Park CS, Choi JY (2010) Quality characteristics of the mashes of Takju prepared using different yeasts. Korean J Food Sci Technol, 42, 56-62

26. Lee SM, Lee ST (2000) Effect of roasted rice and defatted soybean on the quality characteristics of Takju during fermentation. J Natural Science Swins, 12, 71-79
27. Jun Mei, Qizhen Guo, Yan Wu, Yunfei Li, Huaning Yu (2015) Study of proteolysis, lipolysis, and volatile compounds of a Camembert-type cheese manufactured using a freeze-dried Tibetan kefir co-culture during ripening. Food Sci Biotechnol, 24, 393-402

28. Batty D, Waite-Cusic Joy G, Meunier-Goddik L (2019) Influence of cheese-making recipes on the composition and characteristics of Camembert-type cheese. J Dairy Sci, 102, 164-176 